\title{
CONTRASTIVE APPROACH TO NUMERIC USAGE IN JAPAN AND IN THE ABAJADUN METHOD
}

\author{
Nani Sunarni $^{{ }^{*}}$, Eka Kurnia Firmansyah ${ }^{2}$, Zulfi Abdul Malik ${ }^{3}$, Yani Rohmayani ${ }^{4}$ \\ $1^{*}, 2,3,4$ Universitas Padjadjaran, Bandung, Indonesia. \\ Email: ${ }^{1 *}$ nani.sunarni@unpad.ac.id, ${ }^{2}$ eka.kurnia@unpad.ac.id, ${ }^{3}$ zulfiabdulmalik@ gmail.com, \\ yani.rohmayani@unpad.ac.id \\ Article History: Received on $28^{\text {th }}$ March 2020, Revised on $18^{\text {th }}$ May 2020, Published on $17^{\text {th }}$ June 2020
}

\begin{abstract}
Purpose: The article presents both numeric implementation in Japan and the Arabic gematrical calculation (hisababajadun) in Indonesia. It is common for the people in Japan and Indonesia to believe in the power of numerals and to assume whether or not certain digits induce bad luck.
\end{abstract}

Methodology: The research applies a qualitative descriptive method through a contrastive approach.

Main Findings: Data analysis is based on both Koizumi's approach (1995) to the meaning of numbers in the Japanese language and Al Bani's view on hisababajadun. Our study shows that the numeric calculation in Japan uses luckiness as its ground while the hisababajadun builds its mechanism on birth date calculation according to Quranic NeuroHypnosis.

Implications/ Applications: The research may enrich existing theoretical references on the belief toward numbers in both Japan and Indonesia. While in practice, it may as well be a reference for the application of numeric calculation methods in both cultures.

Novelty/Originality of this study: This study is unique and novel as it enhances the understanding of the importance of numerals in two distinct cultures i.e., Japan and Indonesia. Moreover, this study sheds light on some crucial aspects of numeral calculation including how these numerals are used, what beliefs are attached to them and how and where these numerals are used for solving life problems.

Keywords: Abajadun, Japan, Numerical Value, Quranic Neuro-Hypnosis, Constructive Approach.

\section{INTRODUCTION}

Japan is located on the eastern continent of Asia. The country was neighbouring with China and Korea on the west, Karafuto Sakhalin on the north, and neighbouring Taiwan on the south (Toyoda et.al, 1984: 1). In terms of belief, Japanese people believe in magical powers such as those possessed by tombs, animals, jackfruit, and others (Simon, 1952: 281). This is in common with the beliefs of other Asian people (Kalsum, 2011: 31). Japanese Society believes in the existence of good fortune or ten'unron and bad luck or tenkenron (Rahmat in Maebayashi\&Hanzawa, 2020: 3 ). One of the things that are considered to have supernatural powers by Japanese people including "numbers". Japan imports culture from China, especially Kanji culture (Nitta et.al., 1990: 281; Abdullah, 1995). Therefore, Kanji (Chinese characters) used by Japanese people has two reading programs, namely the Chinese reading method called onyomi and Japanese reading method called kunyomi.

The Japanese language is composed of three different scripts — hiragana, katakana, and kanji-while also applies Roman characters (romaji) and Arabic numerals (the latter being used mostly to represent numbers) (Kindaiichi, 2002:5).

In this research, numerals refer to a concept in which objects are quantified. Since humans are no longer nomadic and have permanent addresses, they tend to accumulate wealth. To make an inventory of resources, they need to look them over.

Therefore, different people invented certain numeral systems. In 500 BC, the Mayans of America developed its numeral system using primary symbols. The Egyptians based their numerals on hieroglyphs. During the $11^{\text {th }}$ century, the Arabs came up with numerals of which values are between 1 and 9.

The ancient Greeks used the alphabetic system to denote its numerals. Ancient China used rods to form its numbering system. Roman numerals were represented by seven different letters. European trade, books, and colonialism helped popularize the adoption of Arabic numerals around the world. Today, the Arabic numerals are the most common system for the symbolic representation of numbers in the world, including in Japan and Indonesia. That because Arabic numerals are more efficient than Roman and many other types of numerals for calculation (1999:1). The system holds

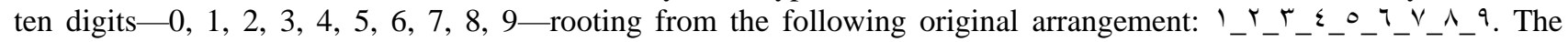
system was introduced to Indonesia by Muslim traders. As time went by, the locals eventually accepted the cultural products like alphabets and language from the Arab Muslims. The local's acceptance shows that the interaction between Malay language and the Arabic language in Indonesia has an incomplete shifted (the speakers continued to use their language along with Arabic as a second language or as adjuvant) (Amiruddin, 2014). 
Therefore, the spread of Islam in Indonesia and the subsequent introduction of the Arabic writing system helped the adoption of Jawi (Malay) and Pegon alphabets of Javanese and Sundanese language in Java. The Arabic writing system was then embraced by local languages that earlier had much been influenced by Pallava writing (Incognitum, 2007; Kridalaksana, 2009). However, the system that was widely used and taken up by local languages in Indonesia differed from the authentic Arabic writing structure. In other words, the Jawi and Pegon alphabets only imitate the graphemes whose phonemes in the Arabic writing system bear the strongest resemblance. As for phonemes that are unlikely represented by Arabic graphemes, the Jawi or Pegon system has rooms for modification, that is, by adding dots or characters to certain graphemes (Abdullah, Laily Ramli, \&Rafek, 2017; Al-Bunni, 1985; Rahman. et.al, 2017).

The Jawi alphabets are no longer used as official scripts in Indonesia. It used to be the standard script for the Malay language during Dutch colonialism but has since been replaced by Latin alphabets. However, in most areas, Jawi or Pegon is still used for particular purposes. It is still adopted in places like Islamic boarding school, majelista'lim, and other traditional religious learning forums, as their religious books are often published in Jawi writing. Besides, the centre of some traditional Islamic boarding schools uses Jawi alphabets to write commentaries on books or teachings.

The influence of Arabic letters in Indonesia is not only found on the extent to which Jawi or Pegon is used. Given the tight link between Islamisation and Arab culture, other forms of Arabic writing may have affected more cultures in Indonesia. Nonetheless, this research only focuses on the impact of Arabic writing in the application of the abajadun method, for one grapheme or Arabic alphabet represents certain numbers. The abajadun method involves units in a grammatical hierarchy like word or phrase whose numerical quantities are valued based on their graphemes. There is a shared belief that the abajadun method can be used for name reading. It may help a person decipher the certain meaning of his/her name through an interpretation of the forming graphemes. We could assume here, through abajadun method, that the Arabic letters are part of inner affairs, intrinsic features of the Unseen (IbnArabi, 2008; Lauder, 2009; Shaghir, 2005).

Akhmad bin Ali Al-Buni in his book, Syamsul Ma'arif Burrows, 2016; Wu, 2017)—which is widely read in Salafi boarding schools - writes that each letter conceives of certain meaning, not to mention a spiritually cosmic secret. When certain letters comprise a word, they would imply an esoteric secret. The word in question may symbolize a bridge by which the real and the mystical are connected. A letter may become a mystical signifier of an event in, or destiny of, one's life. Hence, the formulation is often put to use as a tool for anticipating various matters namely matchmaking, healing, predicting whether or not a bride would suit the groom, and so on. The formulation borrows the abajadun method.

\section{Research Gap and objectives}

Based on the above description, both Japanese and Indonesians believe in numerals. A study to find out how both cultures adopt such belief is required. Accordingly, questions as to how problems are systematized should be put forward.

1 What numerals are considered to have brought either luck or misfortune in the Japanese culture, and what numbers are used in the abajadun method?

2. What is the mechanism in the Japanese culture and the abajadun method, and how both systems are enforced?

3. How has the numeric calculation been technically implemented in the Japanese culture and in the Society where the abajadun method is used for dealing with a certain problem that emerges in one's life?

4. How come the abajadun system applies as one of the alternative means in foretelling one's spirituality or well-being?

\section{METHOD}

As an empirical study, the research relies on both verbal and textual data from direct interviews out of which people's perception or legal development in the Society can be discerned (Maleong, 1999). This research uses the qualitative descriptive method. It explores the implementation of numeric calculation in Japan and in a culture where a Muslimmajority society embraces the abajadun method.

There were several phases of the research namely data collection, data analysis, and conclusion drawing. Data on numeral usage in the Japanese culture was taken through close examination over texts containing numbers or numerals used by the Japanese. Data validity is assessed by using the outputs of our direct observations on the Japanese rituals as a comparison. In the process, it is found that the numbers 3, 5, 7, and 8 are considered to incite luck while the numbers 4 and 9 could lead to bad luck. As regards, data that is required to implement the abajadun system, note-taking and interviews over practitioners were carried out.

Numerical values picked up from interviews and issues concerning the process of implementation of the abajadun system are logged. The data shows that all numbers in the abajadun system are largely positive. Also, elements are underscoring two abajadun calculations and numbers that people use for sacred or special interests. The calculation which deals with Arabic numerals is based on the abajadun system, while the calendrical calculation is based on the Christian calendar. 
The aggregated data is then analyzed based on its daily use. It is later revealed that numbers are subject to daily use, while the abajadun system is applied to three patients whose delivery gap is four months-April, August, and December - between one to another. The corresponding birth months are chosen for the abajadun system to apply effectively even though more patients are healed by the same system. The analysis is based on the theory of Quranic Neuro-Hypnosis developed by Al Buni. The final phase of the research is the conclusion drawn.

\section{RESULT AND ANALYSIS}

\section{Numbers Considered As Blessing And Disadvantage In Japanese Culture And Numbers Used In HisabAbajadun System}

Various cultures in the world look at certain numbers as either bringing good luck or inducing misfortune. In Japanese culture, the numbers 3, 5, 7, and 8 are considered to contribute to blessings. However, the numbers 4 and 9 are thought to have caused adversity. Yet, the abajadun system uses Arabic numerals or alphabets. They are further combined with one's date, month, or year of birth through mathematical addition or subtraction. The followings are the Arabic alphabets (left) and abajadun system (right):
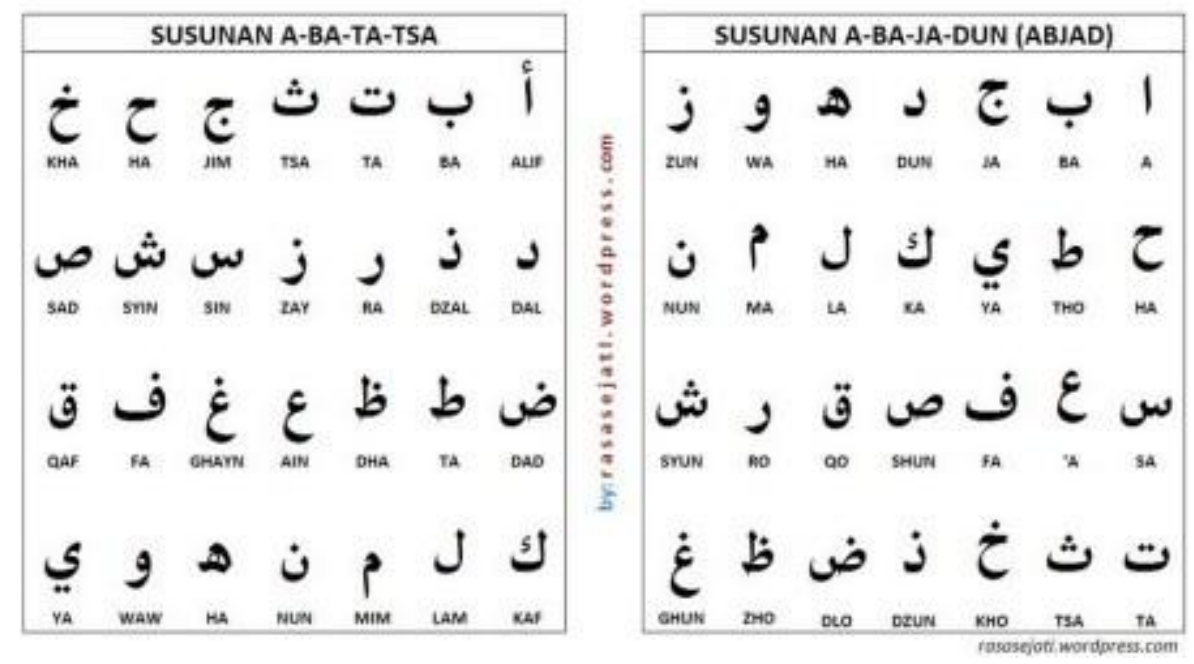

Figure 1: a) Arabic alphabets (left), b) Abajadun system (right)

Source: rasasejati.wordpress.com

Nilai Numerik Huruf Arab (Abjad Arab)

\begin{tabular}{|c|c|c|c|c|c|c|c|c|}
\hline b & & j & 9 & $\Delta$ & $\downarrow$ & $\tau$ & 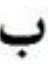 & \\
\hline 9 & $\wedge$ & $V$ & 3 & 0 & \{ & $r$ & $r$ & 1 \\
\hline 9 & 8 & 7 & 6 & 5 & 4 & 3 & 2 & 1 \\
\hline
\end{tabular}

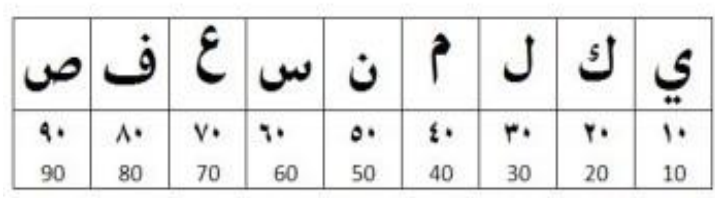

rasasejati.wordpress.com
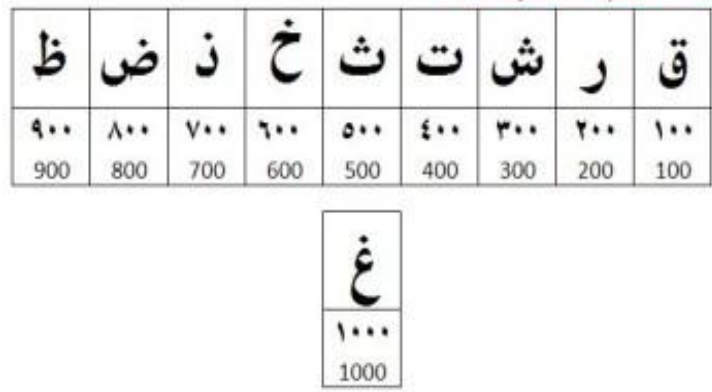

Figure 2: Numbers used in Hisab Abajadun System

Source: rasasejati.wordpress.com 


\section{The Mechanism and Implementation of the Numerical Usage in Japanese Culture and the Abajadun System}

Japan sees the numbers of $3,5,7$, and 8 positively as they are considered to contribute to flukes. 3, 5, and 7 are odd numbers in that they cannot be divisible by two. That is why they are seen as having good qualities. The numbers represent lucky days for staging events that are related to the life of the Japanese.

Shichigosan(七五三) kicks off the festivity. It is a traditional rite of passage in Japan which honours the numbers of seven (shichi -七), five (go -五), and three (san -三). Children who are between the age of 7, 5, and 3 by November 15 observe the day. They will visit a shrine or temple with their families to pray as a symbol of a new phase in life. For three-year-old girls, shichigosan marks a chapter in which they are allowed to leave behind their short cuts and grow their hair out. Boys of five may wear hakama. And girls celebrate their turning seven by tying on their first obi.

Moreover, concerning number 3, Japan observes Hina Matsuri on March 3 to celebrate female children and pray for their continued health and happiness (Saito, 1981) The Japanese cherished the number five and seven.

Japan values the works of literature highly. One of the respected forms is haiku, which is often cited as "the heart of Japan". A haiku often features an image which represents the true Japan as a society. A haiku easily contains words that establish a season as well as the strong feeling of the Japanese as regards the season. Haiku — dubbed the shortest verse form in the world - is often divided into 17 morae or a Japanese unit of syllable weight: five for the first line, seven for the second line, and five for the last line (Wilkinson, 1971; Zaidan, 1943; Zhang, 1999).

Seven in Japan is universally linked with important occasions as much as it is considered a lucky or sacred number. Take New Year's celebration for example. There is a custom to eat nanakusa: seven plants or seven herbs. It is said that these herbs will remove evil from the body and prevent illness from eating too much food during New Year's celebration. In Japan, there is also a naming ceremony for the newborn on the seventh night known as oshichiya. A Japanese saying "nana korobi, yaOki" roughly translates to "Fall seven times, rise eight". There is a list of seven virtues in Japan namely faith (shinnen), hope (kibou), charity (jizen), fortitude (kenning), justice (seigi), temperance (sessei), prudence (shinchou).

Japan also believes that the number eight brings luck. In kanji, it has two strokes which begin from the top and broadens gradually at the base. In other words, two big strokes at the base are deemed unique and artistic (八) as if projecting a better future.

Thus, the strokes symbolize hope for continuing luck. On the other hand, figure-eight symbolizes eternity, which is mirrored on its unbroken loops. In business life, number 8 is often favourable for price tags. For instance, a loaf of bread is offered at 88 yen, fresh milk 288 yen, bean sprouts 38 yen, and so on.

The Japanese have favoured the number 8 of all figures in everything. Although, like zero, it has uninterrupted lines, the number 8 , unlike 6 or 9 , is more unique as it appears the same from any angle.

Many have associated the number eight to wealth. They use it for their bank accounts, house numbers, license plates, telephone numbers, and so forth. Besides, the Japanese see the number 8 as the strongest among other numbers representing the element of earth. Should the number 8 be attached to a jewellery painting, it is believed that good fortune will keep flowing. The number 8 means life. It has two loops about the size of its upper and lower parts. This may mean that there are always two conflicting paradoxes like happiness and sadness, dark and light, black and white, cry and laughter, to name but a few. For the Japanese, the number 8 concludes all for it symbolizes life.

\section{Unlucky Numbers in Japan and in the Society in which the Abajadun Method is accepted}

In Japan, the numbers 4 and 9 are considered to have brought misfortune. Therefore, it is common for them to believe that a great catastrophe or hardship will occur in a place in which 4 and 9 are used. To avoid any adversity from ensuing, those numbers will be averted.

The number four reminds the Japanese of death as it sounds alike (homonym) with the word "死" which means death. The number 9 reminds the Japanese of agony as it sounds like with the word "苦" whose meaning is trouble or sorrow. In Japanese culture, fourth and ninth floors are usually omitted from most elevator fixtures. Neither hotel rooms nor inns make available rooms number four and nine. The same numbers are nonexistent in the most housing complex. Vending machines skip number four. The institution that is authorized to issue vehicle registration plates for motor vehicles does not release plates with such numbers except for special order. However, $3 \mathrm{~A}$ and $8 \mathrm{~A}$ are used as substitutes for the numbers 4 and 9. It often happens that the number 4 does not follow 3 in sequence, as is the case for the number following 8 and preceding 10. All numerals in the dozens, tens, hundreds, thousands, or millions aptly miss 4 and 9 . Why so?

The Japanese kanji is rooted in the Chinese writing system. Kanji readings, therefore, are divided into Chinese way (onyomi) or Japanese way (kunyomi). How come the Japanese consider the numbers 4 and 9 unlucky? The Chinese way of reading four produces the sounds of shi, while the Japanese way results in yon (kunyomi). The sound shi in Kanji has the form ofof死 which means shiny or die. Meanwhile, kanji for the number 9 is 苦 which is read as Ku meaning sorrow 
(kurushii). It has also the ground for the Japanese not to offer things at those amounts. For instance, 42 . If it is read consecutively, it produces the sounds shi-ni (死に) which means death. The complete progression of 4219 will be read by the Japanese as shi-ni-i-Ku (死に行く) which means toward death. Another sequence like 4256 sounds as shi-ni-goro (死に頃), meaning it is time to die. For this reason, certain birthdays are not expected. The Japanese worry about the $42^{\text {nd }}$ and $49^{\text {th }}$ birthdays. Their minds are embedded in thinking that the said birthdays make them prone to diseases and fatal calamity.

Numbers also affect on how people donate Japan. They will pay attention to the amount of charity so as not to have the numbers 4 and 9. Outsiders may look at the belief as a form of tetraphobia: the fear of the number four. According to psychologists, a tetraphobic may be the victim of the mindsets of people around him/her, the neighbourhood one lives in, even an unfortunate event involving the number four.

In Arabic culture numbers commonly used in mathematic counting called hisab. Etymologically, the word hisab (reckoning) is from Arabic, meaning the number or count. In Islam, hisab is commonly used in astronomy. Rukyat Murtadho (2008: 10) in Almanak Hisab says that Ilmu Falak (Islamic Astronomy) branches out to 1) astronomy, 2) astrology, 3) astrophysics, 4) astrometrics, 5) astromechanics, 6) cosmography, 7) cosmogony, and 8) cosmology.

Since the idea of letters expressing a divine order through the relation of the value and their hidden meanings, Arabic letters were related to those branches of astronomy. The relation may occur in Sufi though which assumed that the 28 Arabic letters were created to the number of moon phases, 28 (Hamdan, 2008; Versteegh, 2001).

Hisab al-Jummal is said to have been around since the time of Enoch or Prophet Idris. Modern science calls it gematria, that is, a system to interpret alphabets and numbers (Irfan, 2016; Orfali, 2011; Vredenbregt, 1983). It is a kind of art known since the Babylonian inscriptions during the reign of Sargon II of the Neo-Assyrian Empire (723-705) BC.

The abajadun method is closely influenced by Arabic linguistics as it directly correlates with Arabic phonology. The Arabic language inherits phonemes of other Semitic languages. Debates have been over the origin of phonemes in the Arabic language. However, the strongest theory claims that the Arabic phonemes are rooted from the Phoenician. At least 22 alphabets represent the Phoenician phonemes namely ميح, لومذ, كوف ,يوذ, طيث, حيث, رزاي ,واو ,هي ,دولذ, كومل ,بت, أولف ناو شubarok, 2013).

Moreover, the Arabic language adds six phonemes represented by, الضاض ,الذال, الخاء, الغين, and-Laysi says that the additional phonemes are known as rawadif phonemes. Combined with the Phoenician phonemes, they form أبجدهوزحطيكلمنسعصفرشتنخذضغ . The chain of Arabic phonemes above is recognized as abajadun or abjadi. Some scholars also called those Arabic alphabet patterns the Abjad and, in popular parlance, referred to as Abu Jad (2011:346).

Historically speaking, the abjadi sequence predates the hijai sequence and is referred to as Arabic graphemes. It is based on the phonemic sequence of Old Semitic language and has two different sequences (Al-Jaburi, 2016; Al-Attas, 1970; Wellek, 1995). The Arabs of Eastern Arabia use أبجد هوز حطي كلمن سعف قرشت ثخذ ضظغ. However, the Arabs of western Arabia use أبجد هوز حطي كلمن صعفص قرست ثخذ ضظش. It is believed that the abjadi sequence was developed between the Jahiliyyah and the authority of the fifth Umayyad caliph, Abdul Malik ibn Marwan (685-705 AD). Following difficulties in learning the abjadi order, the hijai sequence — known also as alfabaiy—swapped places. Until today, the hijai order is used in studying Arabic language and other religious learning.

Despite being obsolete, the abjadi order had in its time offered efficient practicality. It initially was used as the phonetic symbols of Arabic language learning. According to Al-Jaburi (2016), there were five benefits of the abjadi order in literacy learning. Firstly, it was used to teach about vocabularies as well as its structure forming. This aims at making known of trilateral (هوز حطي ثخذ ضظغ) and quadrilateral (أبجدكلمن سعض قرشت) formations in the Arabic language.

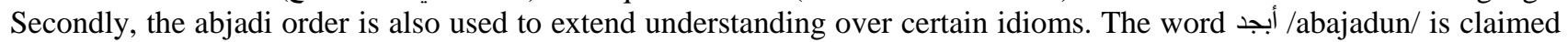
to have meant "to take". While the words هوز/hawazun/ and ي حط /hațayun/ are roughly translated as "to compile" and "to accomplish". Thirdly, the abjadi order addresses students for them to understand, and to evaluate, a semantic relationship that they think important and worthy of use. Considering the semantic relationship between the words /abajadun/, هوز /طي_hawayun/ students are expected to be able to analyze the process of idiom formation. The idea behind it is that it is not effortless to form idioms. Furthermore, the selected word formations are compiled in a structure without which no intentions or ideas could be conveyed (Matsui, 1991; Soebadio, 1975; Tim Penulis, 1980; Tim Penyusun, 2008; Roza, 2017).

Here is a list of Islamic scholars that share commentaries on the abajadun method. Ibrahim ibn Khuttab narrated to us from Ahmad ibn Khalid from Salamahibn Al Fadl from Abdullah ibn Najiyah from Ahmad ibn Al-Ayyami from Amribn Hamid, judge of Ad Dainur city, from Faratibn As Saib from Maimunibn Mahran from Ibn Abbas who said, "all cases can be explained by those who understand them and unidentified by those who do not understand them".

Based on the statement, Ibrahim made clear of every quadrilateral formation as follows:

- ABU JAD (aba Adamu at ta'ah / Adam was reluctant of obeying God and insisted on eating the apple).

- HAWAZUN (zallafaHua minas samai wall ardl/ banished from the heaven and earth). 
- HATHIYYUN (hutthath 'anhukhatayahu/Adam's sin was forgiven).

- KALAMUN (akalaminassyajarahwaMunna 'alaihi bit taubah/eating the forbidden fruit and offered forgiveness).

- SHA'FADHUN (Ashafaakhrajaminanna'imIlannakdy/he had sinned that God expelled him from pleasure (paradise) to pain (world).

- QURAISIYAT (aqarrabidzdzanbifaamanal 'uqubah/he admitted of being sinned and eventually saved from torment).

The second view was narrated by Abdur Rahman ibn Ahmad Al Harwy in its book from Umar ibn Ahmad ibnSyahin from Musa ibnUbaidillah from Abdullah ibnAbiSa'id from Muhammad ibn Hamid dad Salamahibn Al Fadl dad Abu Abdillah Al Bajaly who said: “Abu Jad, Hawaz, Hathy, Kalamun, Sha'afadlun and Quraisiyat are the names of Midian kings".

\section{Medium Used in the Abajadun Method during Medication}

In the supernatural and metaphysical milieu of people of hikmah, three aspects are used for the implementation of the abajadun method. They are birth date, month, year, and the abajadun order, the final result of Arabic numerical values, and the nature and characteristics of each Arabic letter based on four basic elements.

a) Patient's birth date, month, and year

Calculation of the patient's birth date, month, and year using abajadun order.

Every person is entitled to certain wirid (litany) of Quranic verses during medication or when dealing with a problem. The calculation is based on birth date, month, and year. Afterwards, there will be addition and subtraction of final scores based on the number of juz in the Quran. The hijai order is as follows:
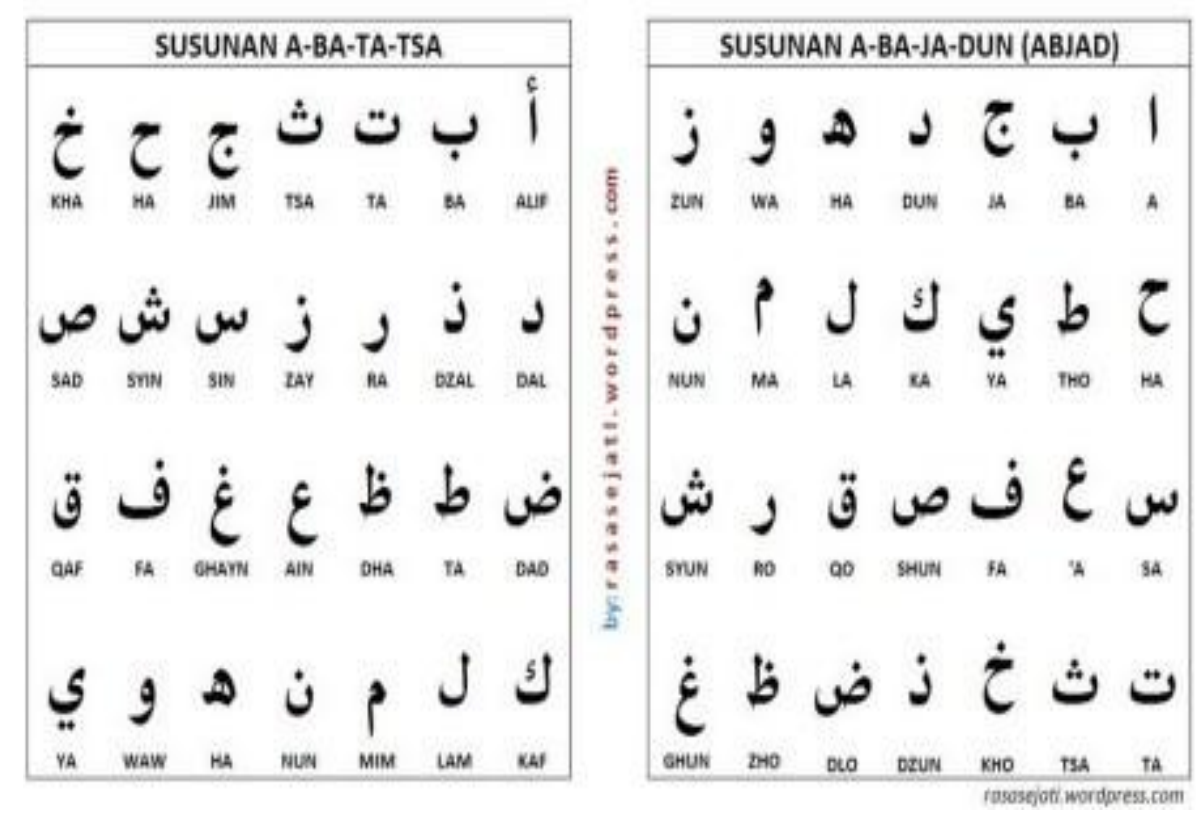

Figure 3: Hijai Order

\section{Numerical values of Arabic letters}

Source: rasasejati.wordpress.com

Each Arabic letter of abajadun order is assigned numerical values. Each value is used to calculate numbers. Every addition of letters will result in a final score with which wirid count is based.

Calculation of name addition based on numerical values of Arabic letters.

Here is the numeral system: $0,1,2,3,4,5,6,7,8$, and 9 . We need to repeat those numbers in the tens, hundreds, and thousands. For instance, to make 10 we choose 1 and 0 of the last single digit $(0,1,2,3,4,5,6,7,8$, and 9). That makes 9 the last single digit. The normal numeral system is infinite. We often mention hundreds, thousands, millions, billions, and so on. However, there is not any "single big number" which can be cited as the last number. Thus, the number 9 is used as the final digit. 

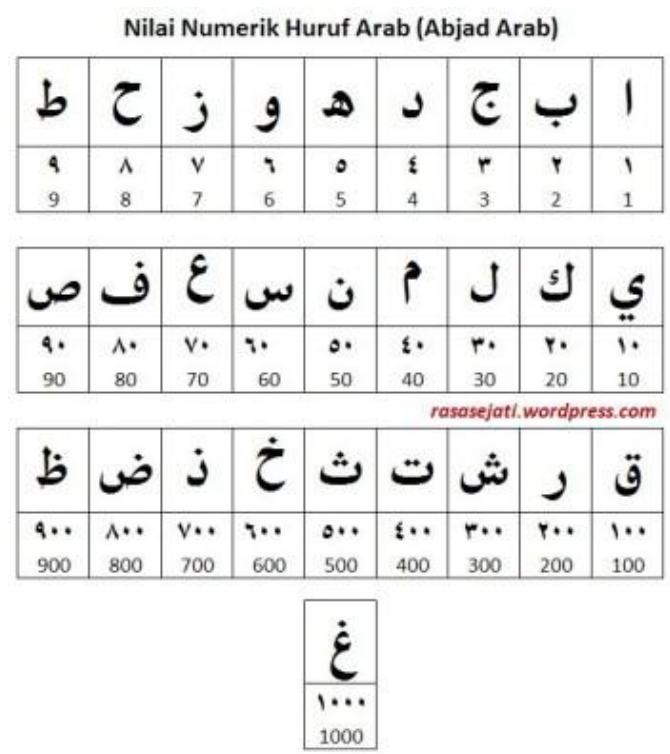

Figure 4: Numerical value of Arabic letters

Source: rasasejati.wordpress.com

a) The nature and characteristics of each letter based on the four elements of nature.

The abajadun method accentuates the nature of each Arabic letter as having any one of four basic elements namely fire, air, water, and earth. Before determining the elements of a letter, draw a box divided into eight columns and four rows. Then, write down consecutively from left to right fire (naariyyun), air (hawaa-iyyun), water (maa-iyyun), and earth (turaabiyyun). Afterwards, the abajadun method should apply to all cells with the final result as follows.

Letters of fire element include alif, ha, ta, mim, fa, shin, dhal

Letters of air element include ba, waw, ya, nun, sad, ta, dla

Letters of water element include Jim, zay, kaf, sin, qaf, tha, za

Letters of the earth element include dal, ha, lam, ayn, ra, Kha, ghayn

\begin{tabular}{|c|c|c|c|}
\hline $\begin{array}{c}\text { Tanah } \\
\text { تران }\end{array}$ & $\begin{array}{l}\text { Air } \\
\text { مائي }\end{array}$ & $\begin{array}{c}\text { Udara } \\
\text { هوائي }\end{array}$ & $\begin{array}{l}\text { Api } \\
\text { ناري }\end{array}$ \\
\hline 2 & $\tau$ & ب & 1 \\
\hline$\tau$ & j & , & o \\
\hline$J$ & 4 & ي & $b$ \\
\hline$\varepsilon$ & س & ن & ? \\
\hline , & ق & ص & 3 \\
\hline$\dot{\tau}$ & ث & ت & ش \\
\hline$\dot{\xi}$ & $b$ & ض & i \\
\hline
\end{tabular}

Figure 5: The nature and characteristics of each letter based on the four elements of nature

Source: rasasejati.wordpress.com

\section{The Implementation of the Abajadun Method for Healing}

a) Decoding birth date, month, and year by using the Abajadun order

The abajadun method is said to have been efficient in determining the amount of Quranic verses a person requires for doing litany (wirid) while curing his/her illness or working on his/her problem. The calculation is based on one's birth date, month, or year by which a foundation to find out the end values that are resulted from either adding or subtracting certain Quranic juz is needed.

Resting on our data, the abajadun method is implemented on several patients born in April, August, and December. Here is an example of the implementation of such a method on a patient who was born in April: 
- When one was born on April 10, 1980 - taking into account April is the fourth month of the year-the result is as follows:

Table 1: Calculation for a patient born in April

\begin{tabular}{lll}
\hline $1 \cdot$ & April & $19 \wedge \cdot$ \\
\hline $1 \cdot$ & $\varepsilon$ & $(1+9)+\Lambda \cdot$ \\
\hline $1 \varepsilon$ & & $1 \cdot+1=11$ \\
\hline
\end{tabular}

Here is the mathematical expression: $14+18=32$.

The sum from the addition, 32, is then subtracted by the total juz in the Quran: $30(32-30=2)$.

Therefore, the said person must recite the second juz of the Quran as his/her litany.

To be precise, the person has to recite the first, fourth, and eighth verses of the second Quranic juz.

It is extracted from the number 14, which is resulted from the addition of the birth date and month plus 8 as the highest sum value of his/her two last digits of birth year of 80 .

Finally, s/he must recite the $142^{\text {nd }}, 145^{\text {th }}$, and $149^{\text {th }}$ verses of Al Baqarah, which is part of the second Quranic juz.

- When one was born on August 8 of 2001 — taking into account August is the eight-month in the year-the result is as follows:

Table 2: Calculation for a patient born in August

\begin{tabular}{lll}
\hline$\Lambda$ & August & $r \cdot \cdot 1$ \\
\hline$\Lambda$ & $\Lambda$ & $(r+\cdot)+\cdot 1$ \\
\hline 17 & & $r+1=r$ \\
\hline
\end{tabular}

Here is the mathematical expression: $16+3=19$.

The sum of addition, 32, is then subtracted by the total juz in the Quran: $30(30-19=11)$.

Therefore, the person has to recite the eleventh juz of the Quran as his/her litany.

Besides, s/he must recite the first and sixth verses of the eleventh Quranic juz.

It is extracted from the number 16, which is resulted from the addition of birth and month plus 1 as the highest sum value of his/her two last digits of birth year of 01 .

Finally, s/he must recite the $94^{\text {th }}$ and $99^{\text {th }}$ verses of At-Tawbah, which is part of the eleventh juz.

- When one was born on December 5, 1986 - taking into account December is the $12^{\text {th }}$ month in the year-the result is as follows:

Table 3: Calculation for a patient born in December

\begin{tabular}{lll}
\hline 0 & December & $19 \wedge \uparrow$ \\
\hline 0 & $1 Y$ & $(1+9)+(\Lambda+7)$ \\
\hline$I V$ & & $1 \cdot+1 \Sigma=r \Sigma$ \\
\hline
\end{tabular}

Here is the mathematical expression: $17+24=41$.

The sum of addition, 41, is then subtracted by the total juz in the Quran: $30(41-30=11)$.

Therefore, the person has to recite the eleventh juz of the Quran as his/her litany.

Besides, s/he must recite the first, seventh, and fourth verses of the eleventh Quranic juz.

It is extracted from the number 17, which is resulted from the addition of birth and month plus 4 as the highest value of his/her birth year of 24 .

Finally, s/he must recite the $94^{\text {th }}, 97^{\text {th }}$, and $100^{\text {th }}$ verses of At-Tawbah, which is part of the eleventh juz.

b) Numeric calculation of names based on the values of Arabic alphabets

The numeral system is as follows: $0,1,2,3,4,5,6,7,8$, and 9 . Repetition of the numbers is required to put them in the tens, hundreds, and thousands. For instance, the pair 1 and 0 taken from the list of single digits $(0,1,2,3,4,5,6,7,8,9)$ are required to form the integer 10, making the number 9 as the last single digit.

A normal numeral system is infinite, frequently cited as hundreds, thousands, millions, billions, and so forth. However, there is no "one big number" that may be called the last number beyond which other numbers are possible. Thus makes the number 9 as the single digit in which repetition is absent. 
Hikmah — a concept in Islamic philosophy and law_-borrows the Abjadiya Principle in implementing the Hijai order in that every letter bears numerical value. Here are examples of how Arabic letters and numerical values are applied to seek values of a person's name, names of God, and Quranic verses.

For instance, the method is often implemented to find out the required amount of wirid as regards certain names of God. In this case, using the method, one can recite "Al-Khabir" (the All-Aware) for 812 times; "Al-Lateef" (The Subtle, The Most Gentle, The All-Kind) for 129 times; "Basmalah" for 786 times; and so forth. The amount in which they are recited is calculated by the Abjadiya principle. The explanation is as follows:

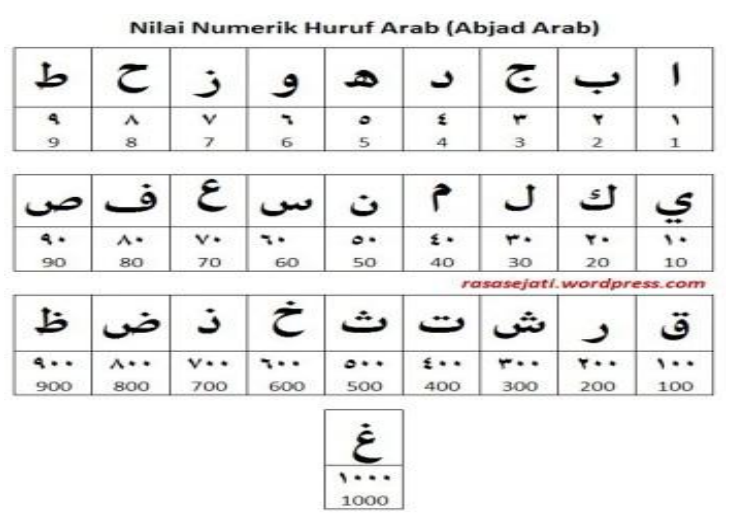

Figure 6: Numerical value of Abjad Arab

Source: rasasejati.wordpress.com

For instance: Al-Khabir خ خ ب

From the numerical values of Arabic letters, here is the calculation:

\begin{tabular}{|c|c|}
\hline Kha & $=$ \\
\hline$b a$ & $=$ \\
\hline$y a$ & $=$ \\
\hline$r a$ & $\equiv$ \\
\hline
\end{tabular}

The amount of Al-Khabirwirid recited based on the calculation using the abajadun method is 812 times.

c) The calculation of one's nature and characteristic based on four basic elements.

Each letter carries a distinct nature of four basic elements of fire, air, water, and earth. To find out the element of each letter, draw a box divided into eight columns and four rows. Afterward, write down the following words from left to right successively: fire (naariyyun), air (hawaa-iyyun), water (maa-iyyun), and earth (turaabiyyun). Subsequently, fill all rows and columns available starting from the top-right with applying the abjadiya method in succession. Here is the result:

Letters of fire element include alif, ha, ta, mim, fa, shin, dhal

Letters of air element include ba, waw, ya, nun, sad, ta, dla

Letters of water element include Jim, zay, kaf, sin, qaf, tha, za

Letters of the earth element include dal, ha, lam, ayn, ra, Kha, ghayn

Based on the nature and characteristics of the four basic elements, the following description may be taken into consideration:

1. Fire

It symbolizes zeal, passion, energy, and strength. It is commonly associated with the enhancement of energy, empowerment, persuasion, cause of conflict, dignity, leadership, and so forth.

2. Air

It symbolizes communication, new ideas, logic, and social skill. Air is associated with the improvement in communication skills, healing of lung diseases, the advancement of intelligence, and so forth.

\section{Water}

It symbolizes peace, meditation, consciousness, and emotion. It is associated with healing, affection, comfort, harmony, mental/emotional balance, intuitive power, love, and so forth. 


\begin{tabular}{|c|c|c|c|}
\hline $\begin{array}{c}\text { Tanah } \\
\text { تر }\end{array}$ & $\begin{array}{l}\text { Air } \\
\text { مائي }\end{array}$ & $\begin{array}{l}\text { Udara } \\
\text { هو أتي }\end{array}$ & $\begin{array}{l}\text { Api } \\
\text { ناري }\end{array}$ \\
\hline 2 & $\Xi$ & ب & 1 \\
\hline$\tau$ & j & , & 0 \\
\hline$J$ & 5 & ي & $b$ \\
\hline$\varepsilon$ & س & ن & ? \\
\hline , & ق & ص & 3 \\
\hline$\dot{\tau}$ & $ث$ & $ت$ & ش \\
\hline$\dot{\varepsilon}$ & $b$ & ض & j \\
\hline
\end{tabular}

Figure 7: The calculation of one's nature and characteristic based on four basic elements

Source: rasasejati.wordpress.com

It symbolizes stability, physical dimension, manifestation. It is associated with patience, wisdom, the capacity to 'debilitate' others, and so forth.

The doer needs to prepare the writing toward the designated directions to highlight the characteristics of each element:

- FIRE, facing towards the EAST

- AIR, facing towards the WEST

- WATER, facing towards the NORTH

- EARTH, facing towards the SOUTH

The Implementation of Numeric Calculation in Japan as well as the Application of the Abajadun Method and Technique as Alternative Means for Answering Life Problems

Based on the understanding of men of hikmah, more efforts are needed to purify one's heart accurately in the current millennium. Aside from innumerable luring worldly temptations, one's appreciation towards the value of knowledge seems to have constantly deteriorated. One of the many complicated cases now is that a spiritual tutor appears only once in a blue moon. Moreover, finding a place of silence and serenity for solitary retreats is not easy.

In terms of faith, supernatural knowledge is now superficially cherished, if not seen frivolously, when in fact it plays a fundamental role in esoteric 'ilm. There are three key elements to master myriad supernatural features: passion and belief, murshid (guide), and heart control.

For someone to become a supernaturalist, it is important that s/he follows the path with passion instead of desperation. Here is a way of interpreting passion and belief: one that comes out of mind as passion, and one that emanates from the heart as belief.

Passion may not materialize if it only presents to the mind especially when the heart does not hold firm conviction. For instance, we are told to fast and to recite wirid for seven days in a row. Simply being passionate is not enough. It is the heart that remains strong which will help you dispel some doubt. It is common to be passionate about doing wirid for the first night. However, during the second night, we may start to feel weary and overfilled. As a result, our mind will wander miserably, creating a sense of fatigue, lethargy, fear, hunger, and so forth. The initial motive of fasting is removed as our body is no longer true to our objective.

A genuine supernaturalist will keep track of its "passion which comes out of the heart"—a belief-because his/her will to finish the rituals is greater than his/her clinging to negative minds. Therefore, the master-disciple relationship is paramount to the spiritual path. While the master supervises his/her disciple in forging his/her belief, the master may encourage the disciple to follow his/her steps or to take in his/her teachings.

When a supernaturalist finally understands the meaning of passion, belief, as well as appreciation toward 'ilm that the murshid has shared, the said supernaturalist may proceed with his/her capability of controlling the heart until all wishes are easily fulfilled. Hence, it is fundamental for the disciple to reach such level by learning the secret of the abajadun letters. 
Table 4: Similarity and Difference of Numeric Usage in Japan and the Abajadun Method

\begin{tabular}{|c|c|c|c|}
\hline \multirow{2}{*}{$\begin{array}{l}\text { Similarity } \\
\text { Japanese }\end{array}$} & & \multicolumn{2}{|l|}{ Difference } \\
\hline & Abajadun & Japanese & Abajadun \\
\hline \multirow[t]{4}{*}{$\begin{array}{l}\text { Both use } \\
\text { determinants. }\end{array}$} & "numerals" as the & $\begin{array}{l}\text { Numbers/numerals are } \\
\text { determined based on } \\
\text { their sounds and } \\
\text { meanings. }\end{array}$ & $\begin{array}{l}\text { Numbers/numerals are } \\
\text { obtained from the } \\
\text { calculation of the birth } \\
\text { date, month, and year. }\end{array}$ \\
\hline & & $\begin{array}{l}\text { Numbers/numerals are } \\
\text { used to determine } \\
\text { events/celebrations. }\end{array}$ & $\begin{array}{l}\text { Numbers/numerals used } \\
\text { for healing, finding a } \\
\text { wedding day, moving } \\
\text { out, and so forth. }\end{array}$ \\
\hline & & $\begin{array}{l}\text { Singularity in shapes is } \\
\text { believed as bringing } \\
\text { luck. }\end{array}$ & $\begin{array}{l}\text { Considered as shirk } \\
\text { (idolatry). On the other } \\
\text { hand, it may be a way of } \\
\text { healing or dealing with } \\
\text { problems. }\end{array}$ \\
\hline & & $\begin{array}{l}\text { Addition and } \\
\text { subtraction uniqueness } \\
\text { do not apply. It is the } \\
\text { uniqueness and } \\
\text { characteristics that are } \\
\text { put into consideration. }\end{array}$ & $\begin{array}{ll}\text { In practice, addition or } \\
\text { subtraction } & \text { is } \\
\text { implemented. } & \end{array}$ \\
\hline
\end{tabular}

\section{CONCLUSION}

Numbers or numerals are used as sacred determinants both in Japan and the abajadun method. In Japan, odd numbers like 3,5, and 7 as well as number 8 are considered to bring luck. However, the abajadun method shows that no numbers are associated with either luck or misfortune, for it shares the same basis for numerical values. The only determinant is but the final calculation of the numbers at issue.

The invention of numbers/numerals has indeed benefited humans. Moreover, it may be claimed that such a calculation signifies the advancement of a nation. It is normal for certain people to believe that some numbers spark blessings while other numbers lead to mischances.

People of hikmah prioritize the use of the abajadun method as an alternative for dealing with life problems. In Japan of in places where the abajadun method is embraced, numbers/numerals become the determinants. The 'ilm of hikmah uses the Hijai order - commonly known as the Abjadiya Principle - in which every letter has a numerical value.

\section{LIMITATION AND STUDY FORWARD}

The authors are advised to extend this work in the future to overcome the limitations of this study. This study covered numeral calculations in only two cultures, i.e., Indonesia and Japan. However, numeral calculations and its use for tackling life problems are extremely prevalent in countries like India, Pakistan, Bangladesh and Nepal. Authors encourage researchers to include the perspectives from these countries as well to get a holistic view and comprehensive findings.

\section{ACKNOWLEDGEMENT}

No financial or non-financial is received from any party for this study. The authors reaffirm that there's no conflict of interest. Thanks to the Faculty of sciences Universitas Padjadjaran, Indonesia, for its support and for providing us the opportunity to enhance our knowledge by conducting this valuable research work.

\section{AUTHORS CONTRIBUTION}

Nani Sunarni worked on the initial writeup, Eka Kumia Firmansyah worked on data collection and analysis and Zulfi Abdul Malik and Yani Rohmayani worked on data interpretation and proofreading of the final draft.

\section{REFERENCES}

1. Abdullah, H. W. M. S. (1995). Malay writing/spelling in jawi manuscripts and printed texts: A comparative analysis. In International Seminar on Malay Manuscripts, Malaysia.

2. Abdullah, N. H., Laily Ramli, N. H., \&Rafek, M. (2017). Mass lecture in language learning: What do the boys and girls think? Journal of Advances in Humanities and Social Sciences, 3(2), 115-123. https://doi.org/10.20474/jahss-3.2.5

3. Al-Attas, S. M. N. (1970). The correct date of thetrengganu incription. Muzium Negara.

4. Al-Bunni, A. A. Y. (1985). SyamsulMa'arif. Al-Maktabah Al-Sya'biyyah.

5. Al-Jaburi, S. (2016). PIn Nizam. Journal of Al-Frahidis Arts2,1-29. 
6. Amiruddin. (2014). Introduction to legal research methods. PT.RajaGrafindo.

7. Burrows, G. (2016). The politics of Arabic script (Unpublished master's thesis). Australian National University, Australia.

8. Hamdan, A. S. (2008). Two messages in the secrets of letters and their meaning. Azhar Heritage Library.

9. IbnArabi, M. A. (2008). Letters secret. In A. S. Hamdan (Ed.), Two messages in the secrets of letters and their meaning (pp. 13-28). Azhar Heritage Library.

10. Incognitum. (2007). Collapse volume i philosopicalreasearch and development. Urbanomic.

11. Irfan, Z. W. (2016). Taste study to Sirnarasa, Tangerang: Jagat 'Arsy Publishing.

12. Kalsum. (2011). Magi in symbols of the sunda people in the cultural rainbow. Uvula Press.

13. Kindaiichi, H. (2002). Nihongo. Oubunsha.

14. Kridalaksana, H. (1991). The old English language: A flower of weakness. Sinar Harapan.

15. Lauder, M., Untung Y., dan Kushartanti. (2009). The first step is to understand linguistics. PT Gramedia Pustaka Utama.

16. Maleong, L. (1999). Qualitative research method. Bandung: P.T. RemajaRosdakarya.

17. Matsui, Y. (1991).How to think of Japanese. The Japan Foundation Japanese Language Institute.

18. Moh. Murtadho. 2008. IlmuFalakPraktis, Malang: UIN-Malang Press.

19. Mubarok, M. (2013). Așwäțu 'L-Sarabiyyah Mina 'T-Tartïbi 'L-Abjaiy Plla 'T-Tartïbi 'Ș-Șawtiy. Majalah Universitas Damaskus, 29,167-203. https://doi.org/10.1163/9789004216136

20. Murtadho, M. (2008). Practical Falak Science. Malang: UIN-Malang Press.

21. Murtadho, M. (2008). Practical falak science. UIN-Malang Press.

22. Nitta, Y. (1990). Japanese language. Oubunsha.

23. Orfali, B. (2011). In the shadow of Arabic: The centrality of language to Arabic culture. Brill. https://doi.org/10.1163/9789004216136

24. Penulis, T. (1980). Indonesia Encyclopedia. IchtiarBaru-Van Hoeve.

25. Penyusun, T. (2008). Indonesia Dictionary. BalaiPustaka.

26. Rahman. (2017).Methods of learning and writing jawi scripts within the malay community: Past and present experiences.In Proceedings of ISER 70th International Conference, Athens.

27. Rahmat, N. (2020). Japanese community's attitude in dealing with the covid-19 plague disaster (Working paper). Japanese Language Study Center. https://doi.org/10.2307/537081

28. Roza, E (2017). Arabic-Malay script in the archipelago and its contribution to the development of intellectual property. At-tsaqofah E-Journal, 13(1),177-204.

29. Saito, R. (1981). Here we survive.HomatsuUniv Press.

30. Shaghir, H. W. (2005). Sheikh Ahmad al-Fatani great thinkers Malays and Islam. National Association of Classical Treasures Pengakajian\&KhazaniahFathaniah.

31. Simon, H. G. (1952). Some Japanese beliefs and home remedies. The Journal of American Foklor, 65(257), 281-293. https://doi.org/10.2307/537081

32. Soebadio, H. (1975). Philology. In Bali-Sunda-Java Regional Infrastructure Seminar, Yogyakarta: UGM.

33. Toyoda, T. (1984). Japanese dust.Bonjinsha.

34. Versteegh, K. (2001). Linguistic contacts between Arabic and other Languages. Brill. https://doi.org/10.1163/157005801323163825

35. Vredenbregt, J. (1983). Research methods and techniques. Gramedia.

36. Wellek, R., \& Warren, A. (1995). Literary theory, Terj. MelaniBudianta. Gramedia Main Library.

37. Wilkinson, R. J. (1971). Paper on Malay subjects. Oxford University Press.

38. Wu, A. A. (2017). A study on learning achievement of integrated songs of Chinese history dynasties into Chinese language teaching at third grade in junior college. International Journal of Humanities, Arts and Social Sciences, 3(5), 192-196. https://doi.org/10.20469/ijhss.3.20001-5

39. Zaidan, J. (1943). Târîkh al-Adab al-'Arabiyyah. Cairo, Egypt: Dâr al-Maârif.

40. Zhang, J. (1999). The representation of numbers. Retrieved from https://pdfs.semanticscholar.org/09e8/72bba80a5112f8b9ce1c0e975f1ed87303fc.pdf? ga=2.210989203.725110 203.1591950725-369192892.1580279637 